\title{
E-LEARNING BERBASIS SCHOOLOGY DAN EDMODO: DITINJAU DARI MOTIVASI DAN HASIL BELAJAR SISWA SMK Tigowati $^{1}$, Agus Efendi ${ }^{2}$, Cucuk W. Budiyanto ${ }^{3}$
}

\author{
Program Studi Pendidikan Teknik Informatika dan Komputer FKIP UNS \\ E-mail: agusefendi@staff.uns.ac.id
}

\begin{abstract}
ABSTRAK
Penelitian ini bertujuan untuk membandingkan hasil belajar kognitif dan tingkat motivasi siswa SMK antara yang menggunakan metode $e$-learning berbasis schoology dengan edmodo. Populasi dalam penelitian ini adalah seluruh siswa kelas X Akuntansi di SMK Negeri 1 Sukoharjo. Sampel terpilih dengan teknik cluster random sampling. Metode penelitian ini menggunakan pretest posttest control group design. Teknik pengumpulan data menggunakan tes untuk data hasil belajar kognitif, kuesioner dan wawancara untuk data motivasi. Uji validitas menggunakan Product Moment dari Pearson dan reliabilitas menggunakan Cronbach's Alpha. Teknik analisis data menggunakan Mixed Methods. Analisis kualitatif menggunakan interactive model.

Hasil penelitian adalah Pertama, Hasil belajar kognitif metode e-learning berbasis schoology lebih baik dibandingkan dengan Edmodo, karena schoology mudah diakses, peserta didik mempunyai target nilai, lebih memahami pelajaran dan lebih aktif pada saat pelajaran yang berdampak pada hasil belajar kognitif. Kedua, Motivasi siswa dengan $e$-learning berbasis schoology lebih baik dibandingkan kelas dengan penggunaan $e$ learning berbasis edmodo, karena schoology membuat tertarik pada pelajaran Simulasi Digital, membuat lebih semangat, lebih senang serta mudah belajar dimanapun dan lebih termotivasi belajar. Tingkat motivasi siswa yang menggunakan e-learning berbasis schoology dan edmodo termasuk kategori sedang.
\end{abstract}

Kata Kunci: E-Learning, Schoology, Edmodo, Motivasi, Hasil Belajar

\begin{abstract}
This study aims to compare the results of cognitive learning and the level of motivation among vocational students who use e-learning method based on schoology with edmodo. The population in this study is all students of class X Accounting at SMK Negeri 1 Sukoharjo. Sample selected by cluster random sampling technique. This research method uses pretest posttest control group design. Data collection techniques used tests for cognitive learning outcome data, questionnaires and interviews for motivational data. Test validity using Product Moment from Pearson and reliability using Cronbach's Alpha. Data analysis technique using Mixed Methods. Qualitative analysis using interactive model.

The result of research is First, the result of cognitive learning of e-learning method based on schoology better than edmodo. because schoology is easily accessible, learners have value targets, more understanding of lessons and are more active during lessons that impact on cognitive learning outcomes. Second, the motivation of students with e-learning based on schoology is better than the class with the use of edmodobased e-learning, because schoology is interested in Digital Simulation lessons, making more passion, more fun and easy to learn wherever and more motivated learning. The level of motivation of students using $e$ learning based on schoology and edmodo is in the medium category.
\end{abstract}

Keywords: E-Learning, Schoology, Edmodo, Motivation, Learning Outcomes

\section{PENDAHULUAN}

Pemerintah RI mendorong dikembangkannya sistem informasi pendidikan berbasis teknologi dan informasi untuk memberikan akses sumber pembelajaran kepada pendidik, tenaga kependidikan dan peserta didik (Peraturan Pemerintah No 17 Tahun 2010, pasal 48 dan 59). Salah satu media pembelajaran yang menggunakan teknologi informasi dikenal sebagai e-learning. Istilah lain dari e-learning yaitu online learning, 
virtual learning, distributed learning, virtual class atau web-based learning. Konsep utama penggunaan e-learning yaitu untuk memudahkan dalam pendistribusian materi pembelajaran, ujian, latihan kuis dan penilaian. Hal ini dilakukan melalui media elektronik atau internet, sehingga siswa dapat mengakses dimana saja dan kapan saja. E-learning platform yang banyak digunakan antara lain Edmodo, Schoology, Moodle, Quipper School, Dokeos, dan $\operatorname{dot} L R N$. Dengan pemanfaatan $e$ learning diharapkan mampu meningkatkan hasil belajar siswa baik berfungsi sebagai suplemen (tambahan), komplemen (pelengkap), maupun substitusi (pengganti) pembelajaran konvensional sesuai dengan pernyataan Siahaan (Darmawan, 2014: 29).

Metode e-learning sejenis lainnya adalah Edmodo. Edmodo diciptakan menggunakan konsep social networking yang mengacu pada jejaring sosial Facebook. Dalam mendukung proses pembelajaran online dilengkapi dengan beberapa aktivitas pembelajaran, seperti quiz, assignment dan poll, serta resource berupa file dan link. Penggunaan istilah course (mata pelajaran) dan group (kelas) pada edmodo tidak dibedakan. Sedangkan schoology memiliki konsep yang sama dengan edmodo dan mendukung hampir semua fasilitas yang didukung oleh edmodo. Namun dalam mendukung pembelajaran online schoology menyediakan banyak pilihan resource, bisa menampung jenis soal (question bank), tersedianya fasilitas attendance/absensi, message dan analityc. Selain itu pada schoology penggunaan istilah course (mata pelajaran) dan group adalah berbeda (Amiroh, 2013).

Edmodo merupakan social network berbasis lingkungan sekolah (school based environment). Edmodo menyediakan cara yang aman dan mudah untuk terhubung dan berkolaborasi antara siswa dan guru untuk berbagi konten pendidikan, mengelola proyek, tugas dan menangani pemberitahuan setiap aktivitas. Edmodo membantu pengajar membangun sebuah kelas virtual sesuai dengan kondisi pembelajaran di dalam kelas, berdasarkan pembagian kelas nyata di sekolah, dimana dalam kelas tersebut terdapat penugasan, kuis dan pemberian nilai pada setiap akhir pembelajaran. Penggunaan media pembelajaran online sebagai sistem pembelajaran yang baru, mendorong penyelenggaraan pembelajaran semakin efektif.

Schoology platform inovatif yang dibangun di atas inspirasi dari Facebook (antar muka dan modelnya, aspek mendasar dengan hadirnya post, update status, berbagi dan memperbarui instan) dan dengan tujuan yang tepat untuk menjadi alat belajar. Menurut (Amiroh, 2013) menyebutkan beberapa kelebihan dari schoology, antara lain: a) Schoology menyediakan lebih banyak pilihan resources daripada yang disediakan oleh Edmodo. b) Schoology dapat menampung jenis soal (question bank) yang akan digunakan saat kuis. c) Schoology menyediakan fasilitas attandance absensi yang digunakan untuk mengecek kehadiran siswa. d) Schoology juga menyediakan fasilitas analityc untuk melihat semua aktivitas siswa pada setiap course, assignment, discussion dan aktivitas lain yang disiapkan untuk siswa

Motivasi menurut Chua \& Don dalam (dalam Castillo-Merino \& Serradell-López, 2014) adalah kekuatan pendorong yang paling penting untuk menjelaskan kemampuan siswa secara online untuk lulus ujian. Motivasi merupakan satu-satunya variabel yang menunjukkan secara langsung dan signifikan berpengaruh terhadap prestasi siswa. Motivasi positif dipengaruhi hanya oleh persepsi siswa sendiri, bahwa siswa yang belajar secara online lebih percaya diri tentang kemampuan belajarnya dan kemudian semakin termotivasi untuk belajar. Mc Donald (Uno, 2014: 73) motivasi adalah perubahan energi dalam diri seseorang yang ditandai dengan munculnya feeling dan didahului dengan tanggapan terhadap adanya tujuan. Dalam belajar diperlukan motivasi. Motivation is an essential condition of learning (Uno, 2014: 84). Hasil belajar akan menjadi optimal, kalau ada motivasi. Makin tepat motivasi yang diberikan, 
akan makin berhasil pula pelajaran. Jadi motivasi menentukan intensitas usaha belajar bagi para siswa. Motivasi berfungsi sebagai pendorong usaha serta pencapaian prestasi. Motivasi yang baik akan menunjukkan hasil yang baik pula. Dengan kata lain, motivasi seorang siswa akan sangat menentukan tingkat pencapaian prestasi belajarnya. Motivasi belajar dapat timbul karena faktor intrinsik, berupa hasrat dan keinginan berhasil dan dorongan kebutuhan belajar, harapan akan citacita. Sedangkan faktor ekstrinsiknya adalah adanya penghargaan, lingkungan belajar yang kondusif, dan kegiatan belajar yang menarik.

Motivasi adalah kondisi penting dalam pembelajaran (Uno, 2014: 84). Pembelajaran yang dilakukan menggunakan e-learning diharapkan dapat menumbuhkan motivasi peserta didik. E-learning mampu mengantarkan siswa untuk mencapai hasil yang lebih baik dan dapat memicu motivasi siswa (Ibrahim \& Suardiman, 2014). Motivasi menurut Chua dan Don (dalam Castillo-Merino \& Serradell-López, 2014) adalah kekuatan pendorong yang paling penting untuk menjelaskan kemampuan siswa secara online untuk lulus ujian. Motivasi merupakan satusatunya variabel yang menunjukkan secara langsung dan signifikan berpengaruh terhadap prestasi siswa. Dan motivasi positif dipengaruhi hanya oleh persepsi siswa sendiri, bahwa siswa yang belajar secara online lebih percaya diri tentang kemampuan belajarnya dan kemudian semakin termotivasi untuk belajar.

Aspek-aspek dalam motivasi belajar menurut Sudjana (2014) antara lain :a) Minat dan perhatian siswa terhadap pelajaran. b) Semangat siswa untuk melaksanakan tugastugas belajarnya. c) Tanggung jawab siswa untuk melaksanakan tugas belajarnya. d) Rasa senang dalam mengerjakan tugas dari guru. e) Reaksi yang ditunjukkan siswa terhadap stimulus yang diberikan guru.

Menurut Hermawan, dkk (Aminoto, 2014) hasil belajar mengacu pada segala sesuatu yang menjadi milik siswa sebagai akibat dari kegiatan pembelajaran yang dilakukan. Oleh karena setiap bidang studi mempunyai tugas tersendiri dalam membentuk pribadi siswa, hasil belajar untuk satu bidang studi berbeda dari bidang studi lain. Belajar dimaksudkan untuk adanya perubahan tingkah perilaku yaitu perubahan dalam aspek kognitif, afektif dan psikomotorik. Perubahanperubahan dimaksudkan berasal dari proses belajar. Perubahan perilaku hasil belajar merupakan perubahan perilaku yang sesuai dengan tujuan pengajaran. (Purwanto, 2013).

Berdasarkan hasil survey yang dilakukan di SMK Negeri 1 Sukoharjo menunjukkan bahwa pembelajaran Simulasi Digital belum optimal. Bahwa penggunaan $e$ learning dalam pembelajaran belum maksimal. Artinya bahwa beberapa guru masih merasa enggan menggunakan. Hal tersebut disebabkan karena terbatasnya pengetahuan dan bagaimana cara mengelola serta memanfaatkan media belajar menjadi lebih inovatif dan kreatif. Hasil belajar kognitif siswa berdasarkan data nilai Ujian Tengah Semester untuk siswa yang menggunakan media e-learning berbeda dengan hasil belajar kognitif siswa yang diajar secara konvensional. Kelas yang menggunakan e-learning (X TKJ 1) rata-rata nilainya lebih tinggi yaitu 91,7 daripada ratarata nilai siswa pada kelas konvensional (X AK 2) dengan rata-rata nilai yaitu 76 . Selain itu motivasi siswa untuk mengikuti pembelajaran tergolong rendah. Saat pembelajaran siswa cenderung ramai, tidak memperhatikan, telat mengumpulkan tugas atau sering ijin keluar kelas.

Pemanfaatan e-learning dapat memberikan pengalaman belajar peserta didik, pengalaman dalam memanfaatkan teknologi dan informasi semakin bertambah. Selain itu dari segi tenaga pendidik atau guru e-learning dapat memudahkan guru untuk mengontrol kegiatan peserta didik, serta menambah interaksi pembelajaran antara peserta didik dengan guru sehingga guru bisa lebih mengetahui kemampuan masing-masing peserta didik. Dari sisi nilai penggunaan $e$ learning mampu meningkatkan nilai peserta didik. Hal ini juga dijelaskan Aminoto dan 
Pathoni (2014) dalam Jurnal Sainmatika Vol 8 No 12014 bahwa penggunaan e-learning dapat meningkatkan hasil belajar siswa dengan peningkatan rata-rata $32 \%$.

Penelitian yang dilakukan Sulistiani dan Sukirno (2016) menunjukkan bahwa pelaksanaan model blended learning berbantuan edmodo dapat meningkatkan motivasi belajar siswa. Peningkatan sebesar 6,8\% berdasarkan kuesioner dari 74,22\% pada siklus I dan 81,09\% pada siklus II. Sedangkan penelitian yang dilakukan Joshua, Swastika dan Estiyanti (2015) menjelaskan bahwa pelaksanaan e-learning menggunakan Schoology memiliki peran besar dalam memberikan motivasi belajar pada peserta didik.

Berbagai alternatif e-learning platform yang dimanfaatkan dalam pembelajaran menyebabkan kebingungan untuk memilih e-learning yang mampu memberikan peningkatan positif. Karena itu perlu kajian atas e-learning platform dan studi perbandingan antar platform. E-learning Schoology dan Edmodo memiliki kemiripan dari segi fitur yaitu adanya fitur asignment, file and links, quiz dan gradebook. Disisi lain ada perbedaan fitur yaitu pada Schoology terdapat fitur attendance, analityc serta tersedia banyak resource yang tidak dimiliki Edmodo. Alasan tersebut yang mendorong untuk mengetahui perbandingan kedua $e$-learning platform.

Berdasarkan identifikasi masalah, maka permasalahan dalam penelitian ini adalah : (1) Apakah terdapat perbedaan penggunaan e-learning berbasis schoology dan edmodo terhadap hasil belajar kognitif pada mata pelajaran Simulasi Digital?, (2) Apakah terdapat perbedaan penggunaan e-learning berbasis schoology dan edmodo ditinjau dari tingkat motivasi siswa SMK pada mata pelajaran Simulasi Digital?

Penelitian ini bertujuan untuk mengetahui perbandingan antara (1) Penggunaan metode $e$ learning berbasis schoology dan edmodo ditinjau dari hasil belajar kognitif siswa SMK (2) Penggunaan metode e-learning berbasis schoology dan edmodo ditinjau dari Tingkat motivasi belajar siswa SMK.

\section{METODE}

Metode yang digunakan dalam penelitian ini adalah metode penelitian kombinasi (mix methods). Penelitian ini merupakan suatu langkah penelitian yang menggabungkan dua penelitian yang telah ada sebelumnya yaitu penelitian kuantitatif dan penelitian kualitatif. Menurut Creswell (2012: 5) penelitian metode campuran merupakan pendekatan penelitian yang mengkombinasikan atau mengaso-siasikan bentuk kualitatif dan bentuk kuantitatif.

Metode kuantitatif dilakukan dengan memberikan test berupa pretest dan posttest untuk mengetahui hasil belajar siswa serta kuesioner untuk mengetahui tingkat motivasi siswa (Creswell, 2012: 24). Analisis data kuantitatif berupa uji keseimbangan untuk mengetahui kemampuan awal siswa, uji normalitas untuk mengetahui apakah data berdistribusi normal atau tidak, uji homogenitas untuk mengetahui apakah data homogen atau tidak dan uji hipotesis. Sedangkan metode kualitatif dilakukan dengan cara wawancara untuk mengetahui persepsi responden mengenai pengaruh penggunaan $e$ learning terhadap motivasi (Creswell, 2012 : 24). Analisis data kualitatif dilakukan dengan menggunakan model interaktif. Dengan menggunakan 4 tahap antara lain pengumpulan data, reduksi data, penyajian data dan penarikan kesimpulan (Miles \& Huberman, 2009: 16).

Sampel penelitian ini adalah siswa kelas $\mathrm{X}$ Akuntansi berjumlah 2 kelas. Kelas $\mathrm{X}$ Akuntansi 1 berjumlah 36 siswa dan kelas $\mathrm{X}$ Akuntansi 3 berjumlah 36 siswa. Teknik pengambilan sampel subjek penelitian dengan cara cluster random sampling, Pengambilan sampel yang dimaksud yaitu mengambil secara cluster dan acak terpilih 2 kelas dengan distribusi 1 kelas menerapkan e-learning edmodo (kelas kontrol) dan 1 kelas menerapkan e-learning schoology (kelas eksperimen). 
Teknik Pengumpulan Data digunakan : (1) metode tes digunakan untuk memperoleh data tentang hasil belajar kognitif yang dilakukan selama 45 menit berupa pretest berjumlah 22 butir soal dan posttest berjumlah 22 butir soal dalam bentuk tes pilihan ganda (multiple choice) secara tertulis sebelum dan sesudah menggunakan media e-learning Schoology dan Edmodo pada mata pelajaran Simulasi Digital. (2) Metode Kuesioner dengan skala likert dengan berjumlah 31 item. Metode kuesioner digunakan untuk mengetahui motivasi siswa.

Aspek yang dipakai dalam kuisioner motivasi belajar antara lain : a) Minat dan perhatian siswa terhadap pelajaran. b)Semangat siswa untuk melaksanakan tugas-tugas belajarnya. c) Tanggungjawab siswa untuk melaksanakan tugas belajarnya. d) Rasa senang dalam mengerjakan tugas dari guru. e) Reaksi yang ditunjukkan siswa terhadap stimulus yang diberikan guru (Sudjana, 2014).

(3) Metode Wawancara; yang dilengkapi dengan lembar wawancara tentang motivasi. Wawancara dilakukan pada 6 responden kelas eksperimen dan 6 responden pada kelas kontrol.

\section{HASIL}

Uji kemampuan awal (pretest) dilakukan uji $t$ independent terhadap hasil data pretest untuk mengetahui apakah terdapat perbedaan atau tidak kemampuan awal (pretest) antara kelas eksperimen dan kelas kontrol. Rangkuman hasil uji hipotesis untuk kemampuan awal (pretest) disajikan dalam tabel 1

Tabel 1. Rangkuman uji t independent terhadap data Pretest

\begin{tabular}{llllll}
\hline Kelas & $\mathrm{N}$ & Sig & $\begin{array}{l}\alpha \\
5 \%\end{array}$ & Kriteria & Keterangan \\
\hline Eksperimen & 36 & 0, & 0,05 & $0,097>$ & $\mathrm{H}_{0}$ diterima \\
Kontrol & 36 & 097 & & 0,05 & \\
\hline
\end{tabular}

Berdasarkan tabel 1 di atas menunjukkan nilai $0,097>0,05$ maka $\mathrm{H}_{0}$ diterima dan $\mathrm{H}_{1}$ ditolak. Artinya kemampuan pretest kemampuan awal siswa tidak berbeda signifikan antara kelas eksperimen dan kelas kontrol. Rata-rata nilai pretest kelas eksperimen yaitu 69,17 sedangkan kelas kontrol yaitu 64,19.
Perbandingan nilai pretest antara kelas eksperimen dan kelas kontrol disajikan pada tabel 2 berikut.

Tabel 2 Perbandingan Presentase Nilai Pretest Kelas Eksperimen dan Kelas Kontrol

\begin{tabular}{ccc}
\hline Interval & $\begin{array}{c}\text { Persentase } \\
\text { Kelas } \\
\text { Eksperimen }\end{array}$ & $\begin{array}{c}\text { Persentase } \\
\text { Kelas Kontrol }\end{array}$ \\
\hline $41-48$ & $5,6 \%$ & $8,3 \%$ \\
$49-56$ & $5,6 \%$ & $19,4 \%$ \\
$57-64$ & $36,1 \%$ & $25,0 \%$ \\
$65-72$ & $19,4 \%$ & $22,2 \%$ \\
$73-80$ & $5,6 \%$ & $16,7 \%$ \\
$81-88$ & $19,4 \%$ & $8,3 \%$ \\
$89-96$ & $8,3 \%$ & $0 \%$ \\
\hline Total & $100 \%$ & $100 \%$ \\
\hline
\end{tabular}

Hasil pretest pada kelas eksperimen persentase paling tinggi yaitu $36,1 \%$ pada interval 57-64 dan persentase paling rendah 5,6 $\%$ pada interval 41-48, 49-56 dan 73-80. Sedangkan hasil pretest pada kelas kontrol persentase paling tinggi yaitu $25 \%$ pada interval 57-64 dan persentase paling rendah yaitu $0 \%$ pada interval 89-96.Perbandingan nilai posttest antara kelas eksperimen dan kelas kontrol disajikan dalam tabel 3 berikut ini.

Tabel 3 Perbandingan Persentase Nilai Posttest Kelas Eksperimen dan Kelas Kontrol

\begin{tabular}{ccc}
\hline Interval & $\begin{array}{c}\text { Persentase } \\
\text { Kelas } \\
\text { Eksperimen }\end{array}$ & $\begin{array}{c}\text { Persentase } \\
\text { Kelas } \\
\text { Kontrol }\end{array}$ \\
\hline $45-52$ & $8,3 \%$ & $11,1 \%$ \\
$53-60$ & $5,6 \%$ & $16,7 \%$ \\
$61-68$ & $5,6 \%$ & $19,4 \%$ \\
$69-76$ & $2,8 \%$ & $2,8 \%$ \\
$77-84$ & $27,8 \%$ & $33,3 \%$ \\
$85-92$ & $36,1 \%$ & $8,3 \%$ \\
$93-100$ & $13,9 \%$ & $8,3 \%$ \\
\hline Total & $100 \%$ & $100 \%$ \\
\hline
\end{tabular}

Hasil posttest pada kelas eksperimen persentase paling tinggi yaitu $36,1 \%$ pada interval 85-92 dan persentase paling rendah 2,8 $\%$ pada interval 69-76. Sedangkan hasil posttest pada kelas kontrol persentase paling tinggi yaitu 33,3 \% pada interval 77-84 dan persentase paling rendah yaitu $2,8 \%$ pada interval 69-76. Bahwa rata-rata kelas eksperimen yaitu 80,08 lebih tinggi daripada kelas kontrol 71,25. Masing-masing kelas mengalami peningkatan hasil belajar kognitif, namun peningkatan yang dialami tidak sama. Peningkatan hasil belajar kognitif kelas 
eksperimen lebih tinggi yaitu 10,91 sedangkan peningkatan pada kelas kontrol yaitu 7,06.

Uji perbedaan kemampuan akhir (posttest) siswa antara kelas eksperimen dan kelas kontrol, dilakukan uji $t$ independent. Berikut ini disajikan rangkuman uji t independent untuk posttest :

Tabel 4. Rangkuman Hasil Hipotesis Posttest

\begin{tabular}{llllll}
\hline Kelas & $\mathrm{N}$ & Sig & $\alpha=5 \%$ & Kriteria & Keterangan \\
\hline Eksperimen & 36 & 0, & 0,05 & $0,008<0,05$ & $\mathrm{H}_{1}$ diterima \\
Kontrol & 36 & 008 & & & \\
\hline
\end{tabular}

Berdasarkan tabel 4. di atas menunjukkan nilai sig 0,008 < 0,05, dapat disimpulkan bahwa terdapat perbedaan nilai posttest antara kelas eksperimen dan kelas kontrol setelah diberikan perlakuan penggunaan e-learning berbasis schoology dan edmodo.

Perbandingan tingkat motivasi antara kelas eksperimen dan kelas kontrol disajikan pada tabel 5 berikut:

Tabel 5 Perbandingan Persentase Tingkat Motivasi Kelas Eksperimen dan Kelas Kontrol

\begin{tabular}{ccc}
\hline Interval & $\begin{array}{c}\text { Persentase } \\
\text { Kelas } \\
\text { Eksperimen }\end{array}$ & $\begin{array}{c}\text { Persentase Kelas } \\
\text { Kontrol }\end{array}$ \\
\hline $79-84$ & $5,6 \%$ & $5,6 \%$ \\
$85-90$ & $16,7 \%$ & $27,8 \%$ \\
$91-96$ & $2,8 \%$ & $25,0 \%$ \\
$97-102$ & $36,1 \%$ & $38,9 \%$ \\
$103-108$ & $33,3 \%$ & $2,8 \%$ \\
$109-114$ & $2,8 \%$ & $0 \%$ \\
$115-120$ & $2,8 \%$ & $0 \%$ \\
\hline Total & $100 \%$ & $100 \%$ \\
\hline
\end{tabular}

Tingkat motivasi pada kelas eksperimen persentase paling tinggi yaitu $36,1 \%$ pada interval 97-102 dan persentase paling rendah 2,8 \% pada interval 91-96, 109-104 dan 115120. Tingkat motivasi pada kelas kontrol persentase paling tinggi yaitu 38,9 \% pada interval 97-102 dan persentase paling rendah yaitu 0\% pada interval 109-114 dan 115-120. Data tersebut membuktikan rata-rata tingkt motivasi kelas eksperimen yaitu 98,94 lebih tinggi daripada kelas kontrol 93,92.

Hasil pengujian perbedaan tingkat motivasi antara kelas eksperimen dan kelas kontrol juga dilakukan uji $\mathrm{t}$ independent. Rangkuman hasil uji perbedaan tingkat motivasi antara kelas eksperimen dan kelas kontrol dilakukan uji t independent ditunjukkan dalam tabel. 6 sebagai berikut ini:

Tabel 6. Rangkuman Hasil Motivasi

\begin{tabular}{lllll}
\hline Variable & Sig & $\begin{array}{l}\alpha \\
5 \%\end{array}$ & Kriteria & Keterangan \\
\hline Motivasi & 0,007 & 0,05 & $0,007<0,05$ & H1 diterima \\
\hline
\end{tabular}

Berdasarkan Tabel 6 di atas menunjukkan nilai sig $0,007<0,05$ dapat disimpulkan bahwa terdapat perbedaan motivasi antara kelas eksperimen dan kelas kontrol setelah diberikan perlakuan penggunaan e-learning berbasis schoology dan edmodo. Kategori tingkat motivasi siswa pada kelas eksperimen yang berjumlah 36 siswa, sebanyak 7 siswa $(19,5 \%)$ memiliki kategori tinggi, 20 siswa $(55,5 \%)$ memiliki kategori sedang dan 9 siswa (25\%) memiliki kategori rendah. Sedangkan tingkat motivasi siswa kelas kontrol yang berjumlah 36 siswa, sebanyak 15 siswa $(41,7 \%)$ memiliki kategori rendah, sebanyak 21 siswa $(58,3 \%)$ memiliki kategori sedang dan tidak ada siswa dalam kategori motivasi tinggi. Dapat disimpulkan bahwa, kecenderungan motivasi kelas eksperimen dan kelas kontrol berada pada kategori sedang. Hal ini berdasarkan pengamatan saat pembelajaran salah satunya yaitu karena infrastruktur yang kurang memadai. Menurut Hendrastomo (2008: 34) terdapat 4 komponen penyokong keber-langsungan e-learning ditinjau dari sisi infrastruktur diantaranya yaitu akses internet, hardware, sistem (software) dan biaya akses. Pada saat pembelajaran berlangsung di dalam kelas, kondisi jaringan internet relatif lambat dan tidak setiap siswa memiliki laptop. Bagi siswa yang tidak memiliki laptop harus bergantian dengan teman sebangku yang menimbulkan keterlambatan dalam mengikuti pembelajaran, sehingga berdampak pada motivasi siswa. Namun disamping itu dari segi biaya e-learning schoology dan edmodo tergolong mudah digunakan dan gratis.

Meskipun tergolong dalam kategori motivasi sedang namun pada kelas eksperimen terdapat 7 siswa $(19,5 \%)$ dalam kategori tinggi dan pada kelas kontrol tidak ada siswa dalam kategori tinggi. Hal ini menunjukkan bahwa $e$ learning schoology lebih berdampak terhadap 
peningkatan motivasi siswa bila dibandingkan dengan edmodo. Temuan ini juga didukung oleh hasil wawancara terhadap 6 reponden pada kelas eksperimen dan 6 responden pada kelas kontrol. Hasil wawancara disimpulkan bahwa e-learning berbasis schoology membuat lebih tertarik pada pelajaran dan lebih aktif dalam pelajaran. E-learning schoology membuat lebih semangat, tidak membuat bosan, lebih memperhatikan pelajaran, mudah dalam mengerjakan tugas, lebih giat belajar, memiliki target nilai, lebih sungguh-sungguh dalam mengerjakan tugas, lebih termotivasi dalam belajar, tepat waktu dalam mengumpulkan tugas, lebih mandiri dalam belajar dan lebih paham dalam pelajaran. Hal ini sesuai dengan penelitian Alif Karyawati dan Kandi Lintang Ndadari (2017) bahwa dengan menggunakan schoology dapat menghemat waktu dan uang dalam menyampaikan tugas, mengakses sumber belajar dengan mudah, merasakan sumber pembelajaran baru dan memanfaatkan media digital untuk belajar.

Meskipun demikian penerapan e-learning berbasis edmodo juga mampu meningkatkan daya tarik siswa, mengikuti pelajaran, membuat siswa lebih memperhatikan pelajaran, membuat siswa lebih antusias, lebih semangat belajar, mudah dalam mengerjakan tugas serta tepat waktu dalam mengumpulkan tugas. Temuan tersebut sejalan dengan Said (2015) bahwa edmodo memfasilitasi dan meningkatkan efektifitas pembelajaran serta dapat menghemat waktu. E-learning berbasis edmodo membuat lebih bertanggung jawab terhadap tugas, lebih membuat senang karena belajar tidak monoton, lebih aktif dalam pelajaran dan lebih paham pelajaran. Hasil wawancara relevan juga dengan penelitian yang dilakukan oleh Sulistiani (2016) dengan hasil penggunaan e-learning edmodo di X AK 2 SMKN 7 Yogyakarta dapat meningkatkan motivasi belajar siswa.

E-learning berbasis Schoology dan edmodo juga memiliki kekurangan bahwa schoology membatasi waktu dalam pengumpulan tugas yang membuat siswa menjadi terbebani. Begitu pula edmodo membuat siswa tidak senang, tidak mempengaruhi semangat belajar karena siswa kurang berminat dengan pembelajaran berupa mengetik, browsing, membuka laptop serta harus selalu terhubung internet. Kelebihan metode e-learning berbasis schoology, lebih meningkatkan motivasi siswa dalam belajar. Siswa lebih berminat dikarenakan mudah dalam mengakses. Tools yang ada mudah dipahami sesuai fungsinya. Siswa memiliki ketertarikan menggunakan media pembelajaran baru yang berbeda dari pembelajaran konvensional. Siswa lebih giat belajar dan bersungguh-sungguh dalam setiap mengerjakan tugas. E-learning berbasis Schoology menumbuhkan sikap siswa lebih mandiri dan masing-masing siswa tidak harus berinteraksi secara langsung dengan guru. Selain itu e-learning berbasis Schoology juga membuat pembelajaran lebih menarik, serta dapat menambah pengetahuan karena resource yang diberikan beraneka ragam.

\section{SIMPULAN}

Hasil penelitian ini dapat disimpulkan sebagai berikut : Pertama, ditemukan adanya perbedaan penggunaan e-learning berbasis schoology dan edmodo terhadap hasil belajar kognitif pada mata pelajaran Simulasi Digital. Hasil belajar kognitif yang menggunakan e-learning berbasis schoology lebih tinggi dengan rata-rata 80,08 daripada kelas yang menggunakan e-learning berbasis edmodo yang rata-ratanya 71,25 .

Kedua, ditemukan adanya perbedaan tingkat motivasi belajar mata pelajaran Simulasi Digital antara e-learning berbasis schoology dan edmodo. Penggunaan metode e-learning berbasis schoology diperoleh nilai rata rata lebih tinggi (rata-rata 98,94) dibandingkan dengan kelas yang menggunakan e-learning berbasis edmodo (rata-rata 93,92). Tingkat motivasi siswa yang menggunakan e-learning berbasis schoology dan edmodo tergolong dalam kategori motivasi sedang. Namun pada kelas yang menggunakan e-learning berbasis schoology memiliki motivasi yang lebih tinggi 
dibanding dengan kelas yang menggunakan edmodo.

\section{IMPLIKASI}

Penggunaan e-learning yang tepat mampu meningkatkan hasil belajar kognitif dan motivasi peserta didik. Selama ini pembelajaran Simulasi Digital disekolah dilakukan secara konvensional, akibatnya peserta didik kurang termotivasi dan hasil belajarnya rendah. Ketika diterapkan $e$ learning berbasis schoology dan edmodo peserta didik cenderung lebih termotivasi dan hasil belajar kognitif mengalami peningkatan dilihat dari hasil pretest dan posttest. Dari segi hasil belajar kognitif dan motivasi e-learning berbasis schoology lebih tinggi dibandingkan dengan e-learning berbasis edmodo. Hasil penelitian ini dapat digunakan guru dalam upaya peningkatan motivasi dan hasil belajar kognitif siswa. Dengan memperhatikan kebutuhan pembelajaran dan karakteristik siswa agar motivasi dan hasil belajar kognitif dapat meningkat.

\section{REFERENSI}

Ardi, P. (2017). Promoting Learner Autonomy Through Schoology M-learning Platform in an Eap Class at an Indonesian University. Teaching English with Technology, 17(2), 55-76, http://www.tewtjournal.org

Arikunto, S. (2013). Prosedur Penelitian Suatu Pendekatan Praktik. Jakarta: Rineka Cipta

Aminoto, T., Pathoni, H. (2014). Penerapan Media E-Learning Berbasis Schoology Untuk Meningkatkan Aktivitas dan Hasil Belajar Materi Usaha dan Energi Di Kelas XI SMA N 10 Kota Jambi. Jurnal Sainmatika, 8 (1), 13-29.

Amiroh. (2013, 2 Januari). Antara Moodle, Edmodo dan Schoology. Diperoleh pada 10 Januari 2017, dari http://amiroh.web.id/antara-moodleedmodo-dan-schoology

Aziz, A. L., Musadieq, M. Al, \& Susilo, H. (2013). Sikap Pengguna E-Learning. Jurnal Administrasi Bisinis, 6(2).

Basori. (2013). Pemanfaatan Social Learning
Network Edmodo dalam Membantu Perkuliahan Teori Bodi Otomotif di Prodi PTM JPTK FKIP UNS, 6(2)

Basuki, I. \& Hariyanto. (2014). Assesmen Pembelajaran. Bandung: PT Remaja Rosdakarya

Besana, S. (2012). Schoology: Il Learning Management System Diventa "social." Strumenti, 20(1), 51-53.

Budiyono. (2009). Statistika Untuk Penelitian. Surakarta: UNS Press

Bungin, B. (2011). Metodologi Penelitian Kuantitatif: Komunikasi, Ekonomi, dan Kebijakan Publik serta Ilmu-ilmu Sosial Lainnya. Jakarta: Kencana

Castillo-Merino, D., \& Serradell-López, E. (2014). An analysis of the determinants of students' performance in e-learning. Computers in Human Behavior, 30, 476-484.

https://doi.org/10.1016/j.chb.2013.06.0 20

Creswell, J, W. (2012). Research Design Pendekatan Kualitatif, Kuantitatif dan Mixed. Terj. Achmad Faawaid. Yogyakarta: Pustaka Belajar. (Buku asli diterbitkan 2009)

Darmawan, A. (2014). Darmawan - Pemilihan Sistem Learning Management ... Pemilihan Sistem Learning Management System (LMS) Metode AHP Menggunakan Criterium Decision Plus 3.0. Faktor Exacta, 7(3), 260-270.

Darmawan, D. (2014). Pengembangan Elearning Teori dan Desain. Bandung: PT Remaja Rosdakarya.

Dong. (2012). Belajar dan Pembelajaran. Bandung: Alfabeta.

Guion, L.A., Diehl, C.D., \& McDonald, D. (2011). Conducting an In-depth Interview. Universitas of Florida IFAS Extension. 2-4

Hake, R, R. (1999). Analyzing Change/Gain Scores. USA: Indiana University

Hanum, N. S. (2013). Keefektifan e-learning sebagai media pembelajaran (studi evaluasi model pembelajaran e-learning SMK Telkom Sandhy Putra Purwokerto). Jurnal Pendidikan Vokasi, 3(1), 90-102. https://doi.org/10.21831/JPV.V3I1.158 4

Hemalatha, S. (2015). E Learning in Health Education - Feasibility, Pros and Cons, 5(3), 34-37. 
Hendrastomo, G. (2008). Dilema dan Tantangan Pembelajaran E-learning. Majalah Ilmiah Pembelajaran, 4(1),3235

Ibrahim, D. S., Suardiman, S. P., \& Yogyakarta, U. N. (2014). The Effects of The Use of E-learning on The Learning Motivation And Achievment in Mathematics, Jurnal Prima Edukasia 2, 66-79.

Irawan, V, T,. Sutadji, E,. Widiyanti. (2017). Blended Learning Based on Schoology : Effort of improvement learning outcome and practicum chance in vacational high school.

Joshua, N., Swastika, P, A,. \& Estiyanti, N, M. (2015). Efektivitas Penerapan Elearning menggunakan Learning Social Network Schoology di Motivasi \& Prestasi Belajar di STMIK. Prosiding Seminar Nasional Pendidikan Teknik Informatika, hlm. 96-101, Fakultas Teknik dan Kejuruan Universitas Pendidikan Ganesha, Bali

Kruse, K. (2013). The Benefit an Drawbacks of e-Learning. Diperoleh pada 10 Januari 2017, dari http://www.elearningguru.com/articles/art_3.htm

Michael, A. (2013). Michael Allen's Guide to E-learning. Canada: John Wiley \& Sons.

Miles, M, B,. Huberman, A, M. (2009). Analisis Data Kualitatif Buku Sumber Tentang Metode-metode Baru. Terj. Tjetjep Rohendi Rohidi. Jakarta: UIPress

Misbahuddin,. Hasan, I. (2014). Analisis Data Penelitian dengan Statistik. Jakarta: Bumi Aksara

Munir. (2007). Pendidikan Dunia Maya, Ilmu \& Aplikasi Pendidikan. Bandung: Imtima

Nazir, M. (2014). Metode Penelitian. Jakarta: Ghalia Indonesia

Nurgiantoro, B. (2013). Penilaian Pembelajaran Bahasa Berbasis Kompetensi. Yogyakarta : BPFEYogyakarta

Pal, S. (2015). Acceptability of Semantic Web Technologies in E-Learning Environment. International Journal of Innovative Knowledge Concepts, 1(4), 47-51.

Peraturan Pemerintah Republik Indonesia Nomor 17 Tahun 2010 tentang Pengelolaan dan Penyelenggaraan
Pendidikan, No. 5105. Sekretariat Negara. Jakarta.

Pranoto, A. dkk. (2009). Sains dan Teknologi. Jakarta: PT Gramedia Pustaka Utama.

Prawiradilaga, D, S., Ariani, D., Handoko, H. (2013). Mozaik Teknologi Pendidikan. Jakarta: Prenamedia Group.

Purwanto. (2013). Evaluasi Hasil Belajar. Yogyakarta: Pustaka Belajar.

Poon, J. (2013). Blended Learning : An Institutional Approach for Enchancing Students' Learning Experiences. MERLOT Journal of Online Learning and Teaching, 9 (2)

Putranti, N. (2013). Cara Membuat Media Pembelajaran Online Menggunakan Edmodo. Jurnal Pendidikan Informatika Dan Sains, 2 (2)(2), 141.

Said, K, M. (2015). Students' Perceptions of Edmodo and Mobile Learning and their Real Barriers towards them. The Turkish Online Journal of Educational Technology, 14(2)

Sardiman. (2014). Interaksi dan Motivasi Belajar Mengajar. Jakarta: PT Raja Grafindo Persada.

Slavin, R. E. (2011). Psikologi Pendidikan: Teori dan Praktik (9th ed.). PT Indeks.

Subiyantoro, E., dkk. (2013). Simulasi Digital Jilid 1. Jakarta: Kemendikbud

Sudibjo, A., Wasis. (2013). Penggunaan Media Pembelajaran Fisika Dengan E-learning Berbasis Edmodo Blog Education Pada Materi Alat Optik Untuk Meningkatkan Respons Motivasi dan Hasil Belajar Siswa di SMP Negeri 4 Surabaya. Jurnal Inovasi Pendidikan Fisika, 2 (3), 187190

Spiegel, M, R., \& Stephens, L, J. (2004). Statsitik. Jakarta: Erlangga

Sicat, A. (2015). Enhancing College Students' Proficiency in Business Writing Via Schoology. International Journal of Education and Research, 3(1)

Sulistiani, F., Sukirno. (2016). Penerapan Model Blended Learning dengan Edmodo untuk Meningkatkan Motivasi dan Prestasi Belajar Siswa. Jurnal Pendidikan Akuntansi Indonesia, 14 (1), 95-103

Sudijono, A. (2008). Pengantar Evaluasi Pendidikan. Jakarta: PT Raja Grafindo Persada.

Supranto. (2009). Statistik Teori dan Aplikasi. Jakarta: Erlangga. 
Sudjana, N. (2014). Penilaian Hasil Proses Belajar Mengajar. Bandung: PT Remaja Rosdakarya.

Uno, B, H. (2014). Teori Motivasi dan Pengukurannya. Jakarta: PT Bumi Aksara.

Widoyoko, E.P. (2013). Evaluasi Program Pembelajaran. Yogyakarta: Pustaka Belajar 